\title{
Teachers' Self-Assessment Towards Technology Integration in Teaching Mathematics
}

\author{
Mel S. Abas, Alex D. David \\ Bataan Peninsula State University
}

\begin{abstract}
The study was designed to determine the teacherrespondents' self-assessment towards technology integration in terms of their competency level in using technology in teaching mathematics; the extent of their student's usage of technology; technologies they used including any obstacles that hinder their effective use of technology. Data were collected from 35 teacher-respondents in a state university in Bataan, Philippines through questionnaire involving teachers' self-assessment regarding technology integration. The findings revealed that the the extent of competency level in using technology was high; they had optimistic assessment on their students' classroom usage in technology and its positive impact to students' behavior in teaching-learning process; Scientific calculator was the most commonly used technology while the least was TV; and they claimed that they need to teach many things twice, with or without the technology as the only variable that is not an obstacle in using technology. This research endeavor is considered significant since its findings will be used as the bases for institutional effectiveness in providing the needed interventions involving technology integration to enhance the teaching-learning process and to make mathematics more interesting and meaningful to both teachers and students. The study will shape plans and directions for future faculty development program and of the university involving technology integration not only in mathematics but also in other fields of the curricular programs of the university.
\end{abstract}

\section{Introduction}

Aside from the traditional pedagogical chalkboard technique in teaching mathematics, nowadays, mathematics instruction may also involve the integration of technology besides the usual utilization of calculators. A mathematics teacher may use any appropriate program of Information and Communications Technology in presenting his or her lesson while others may allow their students to use graphic calculators including electronic gadgets and other modern technologies in the teaching-learning process. Teaching mathematics is such a complex and dynamic profession that it is difficult for a teacher to be advanced or

up-to-date equipped with modern technologies for an effective and efficient teaching. and has become an important aspect of successful teaching and has even triggered many researchers to investigate different aspects of such integration [1]. Today its usage extends well beyond graphing calculators, interactive whiteboards, I-clickers, laptop computers, and iPods [2]. As technological development accelerate in educational settings, connecting academic learning with modern technology can help students gain more opportunities and stimulate interest in exploring learning content [3]. [4] emphasized that technology not only gives learners the opportunity to control their own learning process, but also provides them with ready access to a vast amount of information over which the teacher has no power or control. Technology also allows students to learn more in less time and allows schools to focus on global learning environments if used appropriately. In addition, it could be an effective teaching tool when used to engage all students in the learning process [5]. Some students actually use technology to foster higher thinking skills [3];[6]. On the other hand, teachers must be willing and able to use technology effectively in their teaching in order to realize the benefits that it can offer [7].Although teachers may be taught about new technologies, they might not totally agree on how these technologies can be used to improve their teaching or students' learning [8]. Furthermore, to teachers' personalities and beliefs on teaching, experience with the use of technological tool, support from the school, colleagues, the community, and students' parents might have potential impact on technology integration. More planning effort should therefore be used before implementation [9].

Technology integration in the classroom has come a long way since the 1980s [2]. This study investigates and analyzes teachers' self-assessment on technology integration in teaching and learning mathematics in the six campuses of the Bataan Peninsula State University concerning teachers' methods of integrating the technology, their competency level to technology integration, including the problems and obstacles hindering such integration. Specifically, the study sought to answer the following research questions: (1) How do teachers assess their competencies 
to technology integration in teaching mathematics; (2)To what extent do teachers assess their students' classroom usage of technology?; (3) To what extent do you apply technology Tools in teaching mathematics? (4) How do teachers assess on the obstacles to their effective use of technology in teaching mathematics?; (5) Is there any significant difference between male and female self-assessment of technology integration in terms of (a) their level of competencies in using technology in teaching mathematics; (b) obstacles to their effective use of technology; and (c) students' classroom usage of technologies?

This research endeavor is considered significant since its findings will be used as the bases in providing the needed interventions involving technology integration to enhance the teaching-learning process and to make mathematics more interesting and meaningful to both teachers and students. The study will shape plans and directions for future faculty development program of the university involving technology integration not only in mathematics but also in other fields of the curricular programs of the university.

\section{Methodology}

A descriptive research design was employed based on the objectives stated in the preliminary part of the study. It is the most appropriate design intended to set out the underlying principle for a more explicit approach to evaluate the perceptions and activities of the respondents related to technology integration in teaching-learning process to be better understood. Whatever knowledge it gains is not intended for any practical purposes such as improving the lot of the poor or solving social problem. The knowledge is gained so as to improve on what man already knows and thus expand the frontier of human understanding. It is therefore a search of knowledge for the sake of knowledge. The knowledge it gained may not have social application in the present time but may prove useful in the future. According to Best [10], descriptive research is concerned with "conditions or relationship that exist, practices that prevail; beliefs, points of view or attitudes that are held; processes that are going on; effects that are being felt; or trends that are developing. At times, descriptive research is concerned with how, what is or what exists is related to some preceding event that has influenced or affected the present conditions or event".

A total of 35 teacher-respondents $(92.105 \%$ response rate) from the six campuses of the Bataan Peninsula State University participated in this research endeavor during the academic year 2017-2018. Data were collected through questionnaire involving teachers' self-assessment regarding technology integration. Descriptive statistical tools were employed to analyze the collected quantitative data and group in- terviews were also conducted to gather data concerning other issues hindering such integration or incentives that increase this integration in the class.

\subsection{Instrument}

The study consisted of the survey questionnaire focusing on teachers' self-assessment on technology integration was developed. For research question 1, How do teachers assess their competencies to technology integration in teaching mathematics?, the questionnaire consisted of 20 items subscale. Each item was rated on a 5-point scale, ranging from 1 to 5 using descriptors such as 1 - Very Low, 2 - Low, 3 Moderate, 4 - High, 5 - Very High. Research question 2 involving the extent of teachers' self-assessment on their students' classroom usage of technology consisted of 10-item subscale. Each item was also rated on a 5-point scale, ranging from 1 to 5 using descriptors such as 1 - Strongly Disagree, 2 - Disagree, 3 - Not Sure, 4 - Agree, and 5 - Strongly Agree. For research question 3 , To what extent do you apply technology Tools in teaching mathematics?; the questionnaire contained 12 variables with 5-point scale, ranging from 1 to 5 with the corresponding descriptors such as 1 - Never, 2 - Seldom, 3 - Sometimes, 4 - Often, 5 - Almost Always. For research question 4, How do teachers assess on the obstacles to their effective use of technology in teaching mathematics; the questionnaire consisted of 15 items subscale. Each item was rated on a 4-point scale, ranging from 1 to 4 employing descriptors such as 1 -Always, 2 - Often, 3 - Sometimes, 4 - Not an Obstacle. Lastly, research question 5 involves research hypothesis: Is there any difference in the self-assessment of male and female teachers in technology integration in terms of (a) competencies in technology integration in teaching mathematics; (b) obstacles to their effective use of technology; and (c) classroom usage of technologies?

In the process, the researchers administered the survey questionnaires to mathematics teachers in the six campuses of the Bataan Peninsula State University during the academic year 2017-1018 to gather information regarding their self-assessment of technology integration in teaching mathematics. Group interviews were also conducted to collect data concerning other issues hindering such integration or incentives that may increase this integration in the class. The collected data were interpreted and analyzed to answer the objectives of the study.

SPSS (Statistical Package for Social Sciences) was used to analyze the quantitative data. Descriptive statistics and independent samples t-tests were run to investigate the significant differences between male and female teachers' self-assessment regarding technology integration in teaching mathematics.

For the results of group interviews, the qualitative 
data were only used to support the results collected from the questionnaires. For the purpose of management and analysis, the researchers organized and categorized all the information gathered qualitatively into forms or patterns and later, they only extracted and/or focused on the recurrent patterns of the teachers' views.

\section{Results}

Research Question 1: How do teachers assess their competencies to technology integration in teaching mathematics?

Table 1 shows the means and standard deviations of the respondents' self-assessment of their competency level to technology integration. The mean score on the extent of competency level to technology integration in teaching mathematics as assessed by the respondents is 3.98 which means "high". This high self-assessment of teachers may be due to the fact that technology integration in classroom is part of their teaching pedagogical technique or intervention to enhance the teaching-learning process. Based on the mean scores, it can be gleaned that the respondents are not only proficient in the use of common input and output devices but with mastery in pedagogical content and skills to promote creativity, construction of knowledge by students and facilitate the academic learning in mathematics specially in dealing with problem solving. Teachers are also competent in creating complementary methodical resources based on work with technology resources, developing an open and positive attitude towards technology integration and highly competent in using internet as part of their teaching-learning process.

Table 1. Results of Teachers' Self-assessment on their Competency Level to Technology Integration

\begin{tabular}{|c|c|c|c|c|}
\hline Variable & Mean & $\begin{array}{l}\text { Std. } \\
\text { Deviation }\end{array}$ & Remark & \\
\hline $\begin{array}{l}\text { 1.Proficient in the use of common input and } \\
\text { output devices. }\end{array}$ & 4.09 & .98 & High & \\
\hline $\begin{array}{l}\text { 2.Use technology to locate, evaluate, and collect } \\
\text { mation from a variety of sources. }\end{array}$ & 4.14 & .94 & High & infor- \\
\hline $\begin{array}{l}\text { 3. Mastery of the mathematics content, } \\
\text { skills and the the pedagogical technology use. }\end{array}$ & 4.20 & .80 & High & \\
\hline $\begin{array}{l}\text { 4. Use technology tools and information resources } \\
\text { to promote creativity, and facilitate academic learning } \\
\text { in mathematics. }\end{array}$ & 4.06 & .84 & High & \\
\hline $\begin{array}{l}\text { 5. Use content specific tools like software, simulation, } \\
\text { ate graphing calculators to support learning. }\end{array}$ & 3.26 & 1.17 & High & moder- \\
\hline $\begin{array}{l}\text { 6.Choose learning and technology resources in } \\
\text { teaching mathematics. }\end{array}$ & 3.89 & .90 & High & \\
\hline $\begin{array}{l}\text { 7.Use technology in the development of strategies } \\
\text { for solving mathematics problems in the real-world } \\
\text { situation. }\end{array}$ & 3.86 & .94 & High & \\
\hline $\begin{array}{l}\text { 8. Mastery of a variety of technology resources } \\
\text { associated with the instructional process. }\end{array}$ & 3.97 & .95 & High & \\
\hline $\begin{array}{l}\text { 9.Managing information relevant to, and important for, } \\
\text { the instructional process based on work with } \\
\text { technology sources. }\end{array}$ & 3.94 & .94 & High & \\
\hline $\begin{array}{l}\text { 10.Mobilizing technical abilities for solving problems } \\
\text { in instructional contexts. }\end{array}$ & 4.09 & .98 & High & \\
\hline $\begin{array}{l}\text { 11.Integrating the technology's application with } \\
\text { development of a given pedagogical and } \\
\text { curricular proposition }\end{array}$ & 3.91 & .92 & High & \\
\hline $\begin{array}{l}\text { 12.Systematic planning of the technology's application } \\
\text { so that it is logically integrated into classroom activity. }\end{array}$ & 4.00 & 1.06 & High & \\
\hline
\end{tabular}




\begin{tabular}{|c|c|c|c|}
\hline 13.Implementing processes for applying the technology & 4.03 & .92 & High \\
\hline $\begin{array}{l}\text { 14.Strengthening the classroom teaching proposition } \\
\text { through the implementation of technology tools. }\end{array}$ & 3.97 & .95 & High \\
\hline $\begin{array}{l}\text { 15. Designing concrete technology applications in the } \\
\text { classroom within the instructional process. }\end{array}$ & 3.80 & 1.11 & High \\
\hline $\begin{array}{l}\text { 16.Promoting student learning through the application } \\
\text { of technology tools in the classroom. }\end{array}$ & 3.91 & .78 & High \\
\hline $\begin{array}{l}\text { 17.Creating complementary methodological resources } \\
\text { based on work with technology sources }\end{array}$ & 3.83 & .82 & High \\
\hline $\begin{array}{l}\text { 18. Generating a motivating and collaborative learning } \\
\text { environment through technology integration in the } \\
\text { classroom. }\end{array}$ & 4.09 & .74 & High \\
\hline $\begin{array}{l}\text { 19. Developing an open and positive attitude towards } \\
\text { technology integration, visualizing its possible } \\
\text { contribution to the promotion of learning. }\end{array}$ & 4.26 & .74 & High \\
\hline Knowledge of use of internet as part of teaching- & 4.34 & .80 & High \\
\hline
\end{tabular}

\section{Average Mean: 3.98 (High)}

Research Question 2: "To what extent do teachers assess their students' classroom usage of technology?"

The findings disclosed that teachers had higher self-assessment of students' usage of technology as indicated by the mean score of 3.90 for the items on a 5 -point scale as indicated in table 2 . The respondents reported that their students were interacting and communicating differently with the help of technology and they become more independent learners since it is more interesting and meaningful, become more confident and improved their behavioral engagement in learning mathematics better.

The results are supported by the study conducted by Middleton and Murray [11], the impact of Instructional Technology on students' academic achievement in reading and mathematics, the level of technology used by the teachers had a significant effect on the mathematics achievement of their students.
Likewise, a large number of empirical studies of caculator use, including long-term studies, have generally shown that the use of calculators does not threaten the development of basic skills and that it can enhance conceptual understanding, strategy competence, and disposition toward mathematics. [12]. This report is consistent with the findings of the current study in which the use of calculator as a technology tool helps the students a lot in solving computational problems most specially the engineering students.

In addition, according to the collective findings of 79 research reports, at each grade level, the use of calculators can improve the average students' paperand-pencil skills, both in basic operations and in problem solving. The use of calculators on examinations produced much higher achievement scores and possess a better attitude toward mathematics and especially better self-concept in mathematics than noncalculator students. This applies to all grade and ability levels [13].

Table 2. Results of Teachers' Self-assessment of their Students' Usage of Technology in Classroom

\begin{tabular}{lccc}
\hline \multicolumn{1}{c}{ Variable } & Mean & $\begin{array}{c}\text { Std. } \\
\text { Deviation }\end{array}$ & Remark \\
\hline $\begin{array}{l}\text { 1.Students are interacting and communicating } \\
\text { differently with the help of technology }\end{array}$ & 4.26 & .70 & Agree \\
$\begin{array}{l}\text { 2.Students become more independent learners as } \\
\text { a result of technology. }\end{array}$ & 4.23 & .94 & Agree \\
\hline
\end{tabular}




\begin{tabular}{|c|c|c|c|}
\hline 3.Students use computers only is lab. & 2.57 & 1.06 & Agree \\
\hline $\begin{array}{l}\text { 4.Students are more engaged in learning } \\
\text { mathematics due to technology. }\end{array}$ & 3.71 & .67 & Agree \\
\hline $\begin{array}{l}\text { 5. Students' understanding of mathematics } \\
\text { subjects has deepened due to technology use. }\end{array}$ & 3.86 & .91 & Agree \\
\hline $\begin{array}{l}\text { 6.Students use technology in other subjects aside } \\
\text { from mathematics. }\end{array}$ & 4.29 & .79 & Agree \\
\hline $\begin{array}{l}\text { 7. Students get good grades in mathematics due } \\
\text { to technology integration. }\end{array}$ & 3.63 & .88 & Agree \\
\hline $\begin{array}{l}\text { 8. Mathematics is more interesting and meaningful } \\
\text { to students when using graphics calculators and } \\
\text { other technologies. }\end{array}$ & 4.34 & .68 & Agree \\
\hline $\begin{array}{l}\text { 9. Students become more confident in mathematics } \\
\text { due to technology integration. }\end{array}$ & 4.11 & .80 & Agree \\
\hline $\begin{array}{l}\text { 10.Improve students' behavioral engagement } \\
\text { during lessons and learn mathematics better }\end{array}$ & 4.03 & .66 & Agree \\
\hline
\end{tabular}

Average Mean: 3.90 (Agree)

utilized a number of technology tools in teaching mathematics such as computer, different computer software, internet, overhead projectors, scientific calculators and laptop in teaching mathematics. It also revealed from the findings that scientific calculator was the most commonly used technology in teaching mathematics while the least was TV as reflected in table 3. Mean score for the usage of technology tools is 3.10 which means "sometimes". It shows also that most teachers believed that scientific calculators were a useful technological tool that could aid students to develop inquiry skills and experience problem solving and investigative skills.

The study conducted by Goddard [14] showed that there were increasing number of computers being used at home and an increasing number of technological devices available in schools. The preceding statement conforms to the current findings in which computer and other technological devices laptop, internet and calculators most especially were often or almost always being used by the teacher-respondents in mathematics classroom activities. While Ellington [15] found that calculators had the greatest benefit when used for both instruction and assessment. She noted, however, that "students received the most benefit when calculators had a pedagogical role in the classroom and were not just available for drill and practice or checking work" [16]. Instruction needs to be structured to use technology in non-routine ways (i.e., not in drill and computational practice) - in other words, where students are using it to make decisions and solve problems [17]).

Table 3. Results of Teachers' Self-assessment of their Usage of Technology Tools

\begin{tabular}{llcl}
\hline \multicolumn{1}{c}{ Variable } & Mean & $\begin{array}{c}\text { Std. } \\
\text { Deviation }\end{array}$ & Remark \\
\hline Computer & 3.60 & .98 & Often \\
Transparencies & 2.40 & 1.24 & Seldom \\
Different computer software & 3.00 & 1.03 & Sometimes \\
Internet & 3.57 & 1.06 & Often \\
Overhead projectors & 3.17 & 1.38 & Sometimes \\
Electronic mail & 2.80 & 1.18 & Sometimes \\
Video & 2.81 & 1.12 & Sometimes \\
TV & 2.20 & 1.08 & Seldom \\
Scientific Calculators & 4.8 & .57 & Almost Always \\
Graphic calculators & 2.29 & 1.40 & Seldom \\
Tablet (like i-pad \& others) & 2.57 & 1.34 & Sometimes \\
Notebook or Laptop & 3.86 & 1.16 & Often \\
& & & \\
\hline
\end{tabular}

Average mean: 3.10 (Sometimes) 
Research Question 4: "How do teachers assess on the obstacles to their effective use of technology in teaching mathematics?"

The results as indicated in table 4 showed that the mean score of the items involved is 2.90 which means sometimes. This implies that the majority of the items are in general occasionally encountered as obstacles to the effective use of technology in teaching mathematics as assessed by the mathematics teachers of BPSU. As reflected in the table, the only item that is not an obstacle in using technology as assessed by the respondents is they need to teach many things twice, with or without the technology while limited school resources the respondents need to teach many things twice, with or without the technology while limited school resources and the technology is too expensive for my students barriers in their to afford are considered often encountered by the teacher-
The findings also reveal that teachers are faced with a number of problems or barriers in their teaching with technology. Most of these barriers are, in fact, directly linked to the institution's willingness to provide supports for teachers in addition to providing them with the technology facility. In support to the present findings regarding obstacles that may hinder the effective use of technology in teaching mathematics, there is a lot of research on the views of teacher's about technology use in the classroom. According to Cope and Ward [18], experienced teachers who had little or no professional development in the use of technology in the classroom were less likely to use it in the classroom and were less likely to see the benefit of technology usage in the classroom.

Table 4. Results of Teachers' Self-assessment of their Obstacles to their Effective Use of Technology in Teaching Mathematics

\begin{tabular}{lccl}
\hline \multicolumn{1}{c}{ Variable } & Mean & $\begin{array}{c}\text { Std. } \\
\text { Deviation }\end{array}$ & Remark \\
\hline 1.Lack of personal preparation time & & & \\
2.Inexperience with the technology & 3.20 & .58 & Sometimes an Obstacle \\
3.Insufficient help & 3.21 & .76 & Sometimes an Obstacle \\
4.Limited school resources & 3.00 & .84 & Sometimes an Obstacle \\
5.Using technology means I need to teach many & 2.34 & .94 & Often Not an Obstacle \\
$\quad$ things twice, with and without the technology & 3.51 & .50 & Obstacle \\
6.Lack of course alignment with technology & 3.17 & .62 & Sometimes an Obstacle \\
7.Lack of classroom time & 2.94 & .91 & Sometimes an Obstacle \\
8.The technology is too expensive & 2.31 & .93 & Often Not an Obstacle \\
$\quad$ for my students to afford & & & \\
9.Lack of pedagogical support & 2.74 & .82 & Sometimes an Obstacle \\
10.Lacking of teacher competence & 3.14 & .88 & Sometimes an Obstacle \\
11.Lack of professional development training in & 2.79 & .78 & Sometimes an Obstacle \\
technology integration in teaching mathematics & & & \\
12.No explicit time spent on planning how to & 2.80 & .80 & Sometimes an Obstacle \\
$\quad$ Integrate the technology in teaching mathematics & & & \\
13.Curricula are not ready to use new & 2.63 & .91 & Sometimes an Obstacle \\
$\quad$ technologies & & & \\
14.Using technology is too fraught with technical \\
difficulties & 2.86 & .77 & Sometimes an Obstacle \\
15.Not enough encouragement to use them & 2.94 & .76 & Sometimes an Obstacle
\end{tabular}

Research Question 5: "Is there any significant difference in the self-assessment of male and female teachers in technology integration in terms of (a) competencies in using technology in teaching mathematics; (b) obstacles to their effective use of respondents. The rest of the items are obstacles that are sometimes met by them. technology; and (c) classroom usage of technologies?", results were obtained with the use of t-test to determine if there is significant difference between male and female teacher-respondents regarding their perceptions toward technology integration in teaching mathematics.

The mean of the assessment ratings elicited from the male respondents as well as from female respond- 
ents were used. Table 5 showed the difference between the male self-assessment and female self-assessment of technology integration in terms of their competency in using technology in teaching mathematics. According to t-test results, it can be concluded that female teacher respondents $(x=4.14)$ were more likely to assess that they are competent in choosing learning and technology resources in teaching mathematics $[\mathrm{t}(4.00)=-.61 \mathrm{p}<.01] ;$ mobilizing technical abilities for solving problems in instructional contexts [t(4.36) $=-1.35 \mathrm{p}<.05]$; and integrating the technology's application with development of a given pedagogical and curricular proposition [ $\mathrm{t}(3.93=-1.35 \mathrm{p}<.05]$ than male teacher respondents $(x=3.46)$. Specific results regarding the competency level of male and female teacher respondents are presented in the table.

Table 5. Result of t-test Summary of Male and Female Respondents' Self-assessment of Technology Integrations In Terms of their Competency in Using Technology

\begin{tabular}{|c|c|c|c|c|c|c|}
\hline Variable & Gender & $\mathrm{N}$ & $\mathrm{X}$ & SD & $\mathrm{t}$ & sig \\
\hline $\begin{array}{l}\text { 1. Proficient in the use of common in- } \\
\text { put and output devices. }\end{array}$ & $\begin{array}{l}\text { Male } \\
\text { Female }\end{array}$ & $\begin{array}{l}21 \\
14\end{array}$ & $\begin{array}{c}3.9 \\
4.36\end{array}$ & $\begin{array}{l}1.004 \\
.842\end{array}$ & -1.352 & .335 \\
\hline $\begin{array}{l}\text { 2.Use technology to locate, evaluate, } \\
\text { and collect information from a variety } \\
\text { of sources. }\end{array}$ & $\begin{array}{c}\text { Male } \\
\text { Female }\end{array}$ & $\begin{array}{l}21 \\
14\end{array}$ & $\begin{array}{l}4.05 \\
4.29\end{array}$ & $\begin{array}{l}1.024 \\
.825\end{array}$ & -.726 & .176 \\
\hline $\begin{array}{l}\text { 3. Mastery of the mathematics content, } \\
\text { the pedagogical skills and the technol- } \\
\text { ogy use. }\end{array}$ & $\begin{array}{c}\text { Male } \\
\text { Female }\end{array}$ & $\begin{array}{l}21 \\
14\end{array}$ & $\begin{array}{c}4.05 \\
4.5\end{array}$ & $\begin{array}{l}.775 \\
.760\end{array}$ & -1.885 & .360 \\
\hline $\begin{array}{l}\text { 4.Use technology tools and information } \\
\text { resources to promote creativity, and fa- } \\
\text { cilitate academic learning in mathemat- } \\
\text { ics }\end{array}$ & $\begin{array}{c}\text { Male } \\
\text { Female }\end{array}$ & $\begin{array}{l}21 \\
14\end{array}$ & $\begin{array}{l}3.95 \\
4.21\end{array}$ & $\begin{array}{l}.921 \\
.699\end{array}$ & -.913 & .669 \\
\hline $\begin{array}{l}\text { 5.Use content specific tools like soft- } \\
\text { ware, simulation, graphing calculators } \\
\text { to support learning. }\end{array}$ & $\begin{array}{l}\text { Male } \\
\text { Female }\end{array}$ & $\begin{array}{l}21 \\
14\end{array}$ & $\begin{array}{l}3.14 \\
3.43\end{array}$ & $\begin{array}{l}1.352 \\
.852\end{array}$ & -.701 & .055 \\
\hline $\begin{array}{l}\text { 6.Choose learning and technology re- } \\
\text { sources in teaching mathematics. }\end{array}$ & $\begin{array}{c}\text { Male } \\
\text { Female }\end{array}$ & $\begin{array}{l}21 \\
14\end{array}$ & $\begin{array}{l}3.81 \\
4.00\end{array}$ & $\begin{array}{l}1.078 \\
.555\end{array}$ & -.608 & $.002^{* * *}$ \\
\hline $\begin{array}{l}\text { 7.Use technology in the development of } \\
\text { strategies for solving mathematics } \\
\text { problems in the real-world situation. }\end{array}$ & $\begin{array}{l}\text { Male } \\
\text { Female }\end{array}$ & $\begin{array}{l}21 \\
14\end{array}$ & $\begin{array}{l}3.76 \\
4.00\end{array}$ & $\begin{array}{l}1.044 \\
.784\end{array}$ & -.726 & .293 \\
\hline $\begin{array}{l}\text { resources associated with the instruc- } \\
\text { tional process. }\end{array}$ & $\begin{array}{l}\text { Male } \\
\text { Female }\end{array}$ & $\begin{array}{l}21 \\
14\end{array}$ & $\begin{array}{l}3.90 \\
4.07\end{array}$ & $\begin{array}{l}1.044 \\
.829\end{array}$ & -.501 & .220 \\
\hline $\begin{array}{l}\text { 9.Managing information relevant to, } \\
\text { and important for, the instructional pro- } \\
\text { cess based on work with technology } \\
\text { sources. }\end{array}$ & $\begin{array}{l}\text { Male } \\
\text { Female }\end{array}$ & $\begin{array}{l}21 \\
14\end{array}$ & $\begin{array}{l}3.90 \\
4.00\end{array}$ & $\begin{array}{l}1.044 \\
.784\end{array}$ & -.290 & .096 \\
\hline $\begin{array}{l}\text { 10.Mobilizing technical abilities for } \\
\text { solving problems in instructional con- } \\
\text { texts. }\end{array}$ & $\begin{array}{l}\text { Male } \\
\text { Female }\end{array}$ & 14 & 3.90 & $\begin{array}{l}1.136 \\
.633\end{array}$ & -1.352 & $.011^{*}$ \\
\hline $\begin{array}{l}\text { 11.Integrating the technology's applica- } \\
\text { tion with development of a given peda- } \\
\text { gogical and curricular proposition. }\end{array}$ & $\begin{array}{c}\text { Male } \\
\text { Female }\end{array}$ & $\begin{array}{l}21 \\
14\end{array}$ & $\begin{array}{l}3.90 \\
3.93\end{array}$ & $\begin{array}{r}1.09 \\
.616\end{array}$ & -.074 & $.014^{*}$ \\
\hline $\begin{array}{l}\text { 12.Systematic planning of the technol- } \\
\text { ogy's application so that it is logically } \\
\text { integrated into classroom activity. }\end{array}$ & $\begin{array}{c}\text { Male } \\
\text { Female }\end{array}$ & $\begin{array}{l}21 \\
14\end{array}$ & $\begin{array}{l}4.10 \\
3.86\end{array}$ & $\begin{array}{l}1.16 \\
.949\end{array}$ & .647 & .982 \\
\hline
\end{tabular}




\begin{tabular}{|c|c|c|c|c|c|c|}
\hline \multirow{2}{*}{$\begin{array}{l}\text { 13.Implementing processes for apply- } \\
\text { ing the technology that promote con- } \\
\text { struction of knowledge by students. }\end{array}$} & Male & 21 & 3.95 & 1.024 & \multirow{2}{*}{-.592} & \multirow{2}{*}{.562} \\
\hline & Female & 14 & 4.14 & .770 & & \\
\hline \multirow{2}{*}{$\begin{array}{l}\text { 14.Strengthening the classroom teach- } \\
\text { ing proposition through the implemen- } \\
\text { tation of technology tools. }\end{array}$} & Male & 21 & 3.86 & 1.062 & \multirow[b]{2}{*}{-.864} & \multirow[b]{2}{*}{.446} \\
\hline & Female & 14 & 4.14 & .770 & & \\
\hline \multirow{2}{*}{$\begin{array}{l}\text { 15.Designing concrete technology ap- } \\
\text { plications in the classroom within the } \\
\text { instructional process }\end{array}$} & Male & 21 & 3.71 & 1.189 & \multirow{2}{*}{-.556} & \multirow[t]{2}{*}{.744} \\
\hline & Female & 14 & 3.93 & .997 & & \\
\hline \multirow{2}{*}{$\begin{array}{l}\text { 16.Promoting student learning through } \\
\text { the application of technology tools in } \\
\text { the classroom. }\end{array}$} & Male & 21 & 3.76 & .768 & \multirow[b]{2}{*}{-1.435} & \multirow[b]{2}{*}{.954} \\
\hline & Female & 14 & 4.14 & .770 & & \\
\hline \multirow{2}{*}{$\begin{array}{l}\text { 17.Creating complementary methodo- } \\
\text { logical resources based on work with } \\
\text { technology sources. }\end{array}$} & Male & 21 & 3.67 & .856 & \multirow[b]{2}{*}{-1.450} & \multirow[b]{2}{*}{.438} \\
\hline & Female & 14 & 4.07 & .730 & & \\
\hline \multirow{2}{*}{$\begin{array}{l}\text { 18.Generating a motivating and collab- } \\
\text { orative learning environment through } \\
\text { technology integration in the class- } \\
\text { room. }\end{array}$} & Male & 21 & 3.95 & .865 & \multirow[b]{2}{*}{-1.315} & \multirow[b]{2}{*}{.428} \\
\hline & Female & 14 & 4.29 & .469 & & \\
\hline \multirow{4}{*}{$\begin{array}{l}\text { 19.Developing an open and positive at- } \\
\text { titude towards technology integration, } \\
\text { visualizing its possible contribution to } \\
\text { the promotion of learning. } \\
\text { 20.Knowledge of use of internet as part } \\
\text { of teaching-learning process. }\end{array}$} & Male & 21 & 4.19 & .873 & \multirow[b]{2}{*}{-.646} & \multirow[b]{2}{*}{.102} \\
\hline & Female & 14 & 4.63 & .479 & & \\
\hline & Male & 21 & 4.14 & .854 & \multirow[b]{2}{*}{-1.987} & \multirow[b]{2}{*}{.382} \\
\hline & Female & 14 & 4.64 & .633 & & \\
\hline
\end{tabular}

Significant: $* \mathrm{p}<0.05, * * \mathrm{p}<0.01$

Table 6 indicates that there is no significant difference between the male and female teachers' selfassessment of technology integrations in terms of obstacles to their effective use of technology in teaching mathematics based from the mean of the assessment ratings obtained from the respondents. The results also showed that both male and female teacher respondents assessed that "Using technology means I need to teach many things twice, with and without the technology" is not an obstacle to the effective use of technology in teaching mathematics.

Strategic use of technology strengthens mathematics teaching and learning [19]. Strategic use does not imply continuous use of technology. Rather, it refers to teacher and student use of technology tools as determined through decision making that keeps mathematics, and not technology, as the focus of instruction. As they make choices about technology use, teachers and curriculum developers capitalize on capabilities of available tools and attend to possibilities presented by emerging technology, while maintaining a focus on mathematics learning goals, considering instructional settings, and responding to learners. Strategic uses are not limited to those required for external assessments but also include uses of technology to develop students' by-hand procedures [20].
It is also revealed that both male and female teacher respondents assessed that sometimes the following aspects were encountered hindering their effective use of technology in teaching mathematics: Insufficient help, Lack of pedagogical support, Lacking of teacher competence, No explicit time spent on planning how to integrate the technology in teaching mathematics, Using technology is too fraught with technical difficulties, and Not enough encouragement to use them while the limited school resources was often encountered by both male and female teacher respondents hindering the effective use of technology in teaching mathematics.

The pedagogical support plays a very important role in ensuring the success of technology integration program implementation. It is every institution's responsibility to make sure that teachers are provided with excellent instructional approaches/methodologies which should be the function of the academic affairs to assist teachers in integrating technology in the teaching of mathematics. Diem [21] argued that 'teachers who are supported are less likely to feel threatened and develop more positive attitudes toward technology. Teachers should not "get frustrated when using technology" because, if they do, their teaching will be negatively affected. 
Table 6. t-test summary of male and female respondents' perceptions of technology integrations in terms of obstacles to their effective use of technology in teaching mathematics

\begin{tabular}{|c|c|c|c|c|c|c|}
\hline Variables & Gender & $\mathbf{N}$ & $\overline{\mathbf{X}}$ & SD & $\bar{t}$ & sig \\
\hline 1.Lack of personal preparation time & $\begin{array}{l}\text { Male } \\
\text { Female }\end{array}$ & $\begin{array}{l}21 \\
14\end{array}$ & $\begin{array}{l}3.24 \\
3.43\end{array}$ & $\begin{array}{l}.625 \\
.514\end{array}$ & -0.946 & .849 \\
\hline 2.Inexperience with the technology & $\begin{array}{c}\text { Male } \\
\text { Female }\end{array}$ & $\begin{array}{l}21 \\
14\end{array}$ & $\begin{array}{l}3.48 \\
3.07\end{array}$ & $\begin{array}{l}.680 \\
.829\end{array}$ & 1.581 & .665 \\
\hline 3.Insufficient help & $\begin{array}{l}\text { Male } \\
\text { Female } \\
\text { Male }\end{array}$ & $\begin{array}{l}21 \\
14 \\
21\end{array}$ & $\begin{array}{l}3.00 \\
3.00 \\
2.29\end{array}$ & $\begin{array}{l}.837 \\
.877 \\
1.007\end{array}$ & 0.00 & 1.00 \\
\hline 4.Limited school resources & Female & 14 & 2.43 & .852 & -0.436 & .504 \\
\hline $\begin{array}{l}\text { 5.Using technology means I need to } \\
\text { teach many things twice, with and } \\
\text { without the technology }\end{array}$ & $\begin{array}{l}\text { Male } \\
\text { Female }\end{array}$ & $\begin{array}{l}21 \\
14\end{array}$ & $\begin{array}{l}3.52 \\
3.36\end{array}$ & $\begin{array}{l}.512 \\
.497\end{array}$ & 0.954 & .216 \\
\hline $\begin{array}{l}\text { 6.Lack of course alignment with tech- } \\
\text { nology }\end{array}$ & $\begin{array}{c}\text { Male } \\
\text { Female }\end{array}$ & $\begin{array}{l}21 \\
14\end{array}$ & $\begin{array}{l}3.29 \\
3.00\end{array}$ & $\begin{array}{l}.644 \\
.555\end{array}$ & 1.357 & .061 \\
\hline 7.Lack of classroom time & $\begin{array}{c}\text { Male } \\
\text { Female }\end{array}$ & $\begin{array}{l}21 \\
14\end{array}$ & $\begin{array}{l}3.05 \\
2.79\end{array}$ & $\begin{array}{l}.865 \\
.975\end{array}$ & 0.834 & .624 \\
\hline $\begin{array}{l}\text { 8.The technology is too expensive } \\
\text { for my students to afford }\end{array}$ & $\begin{array}{l}\text { Male } \\
\text { Female } \\
\text { Male }\end{array}$ & $\begin{array}{l}21 \\
14 \\
21\end{array}$ & $\begin{array}{l}2.19 \\
2.50 \\
2.76\end{array}$ & $\begin{array}{l}.981 \\
.855 \\
.889\end{array}$ & -0.961 & .858 \\
\hline 9.Lack of pedagogical support & Female & 14 & 2.71 & .726 & 0.167 & .397 \\
\hline 10.Lacking of teacher competence & $\begin{array}{c}\text { Male } \\
\text { Female }\end{array}$ & $\begin{array}{l}21 \\
14\end{array}$ & $\begin{array}{l}3.24 \\
3.00\end{array}$ & $\begin{array}{l}.944 \\
.784\end{array}$ & 0.780 & .166 \\
\hline $\begin{array}{l}\text { 11.Lack of professional development } \\
\text { training in technology integration in } \\
\text { teaching mathematics }\end{array}$ & $\begin{array}{c}\text { Male } \\
\text { Female }\end{array}$ & $\begin{array}{l}21 \\
14\end{array}$ & $\begin{array}{l}2.95 \\
2.50\end{array}$ & $\begin{array}{l}.805 \\
.650\end{array}$ & 1.753 & .653 \\
\hline $\begin{array}{l}\text { 12. No explicit time spent on planning } \\
\text { how to integrate the technology in } \\
\text { teaching mathematics }\end{array}$ & $\begin{array}{c}\text { Male } \\
\text { Female }\end{array}$ & $\begin{array}{l}21 \\
14\end{array}$ & $\begin{array}{l}2.86 \\
2.71\end{array}$ & $\begin{array}{l}.854 \\
.726\end{array}$ & 0.514 & .497 \\
\hline $\begin{array}{l}\text { 13.Curricula are not ready to use new } \\
\text { technologies }\end{array}$ & $\begin{array}{l}\text { Male } \\
\text { Female }\end{array}$ & $\begin{array}{l}21 \\
14\end{array}$ & $\begin{array}{l}2.76 \\
2.43\end{array}$ & $\begin{array}{l}.995 \\
.756\end{array}$ & 1.063 & .415 \\
\hline $\begin{array}{l}\text { 14. Using technology is too fraught } \\
\text { with technical difficulties }\end{array}$ & $\begin{array}{l}\text { Male } \\
\text { Female }\end{array}$ & $\begin{array}{l}21 \\
14\end{array}$ & $\begin{array}{l}3.00 \\
2.64\end{array}$ & $\begin{array}{l}.837 \\
.633\end{array}$ & 1.357 & .732 \\
\hline $\begin{array}{l}\text { 15.Not enough encouragement to use } \\
\text { them }\end{array}$ & $\begin{array}{l}\text { Male } \\
\text { Female }\end{array}$ & $\begin{array}{l}21 \\
14\end{array}$ & $\begin{array}{l}2.86 \\
3.07\end{array}$ & $\begin{array}{l}.793 \\
.730\end{array}$ & -0.808 & .756 \\
\hline
\end{tabular}

The mean of the assessment ratings elicited from the male respondents as well as from female respondents were used. Table 7 shows the difference between the male self-assessment and female self-assessment of technology integration in terms of students' classroom usage of technology in teaching mathematics. According to t-test results, it can be concluded that female teacher respondents $(x=3.96)$ technology in teaching mathematics were more likely to assess that students are interacting and communicating differently with the help of technology in teaching mathematics $[\mathrm{t}(4.36)=-.68 \mathrm{p}<.05]$ and students become more independent learners as a result of technology $[\mathrm{t}(4.6)=-1.8 \mathrm{p}<.05$ than male teacher respondents $(x=3.86)$. Specific results regarding the competency level of male and female teacher respondents are presented in the said table. 
Table 7. t-test summary of male and female respondents' perceptions of technology integrations in terms of their classroom usage of technologies in teaching mathematics

\begin{tabular}{|c|c|c|c|c|c|c|}
\hline Variables & Gender & $\mathbf{N}$ & $\overline{\mathbf{X}}$ & SD & $\mathbf{t}$ & sig \\
\hline \multirow{2}{*}{$\begin{array}{l}\text { 1.Students are interacting and communicating } \\
\text { differently with the help of technology }\end{array}$} & Male & 21 & 4.19 & .814 & \multirow{2}{*}{-.684} & \multirow{2}{*}{$.041^{*}$} \\
\hline & Female & 14 & 4.36 & .497 & & \\
\hline \multirow{2}{*}{$\begin{array}{l}\text { 2.Students become more independent learners } \\
\text { as a result of technology. }\end{array}$} & Male & 21 & 4.00 & 1.095 & \multirow[b]{2}{*}{-1.817} & \multirow[b]{2}{*}{$.045^{*}$} \\
\hline & Female & 14 & 4.57 & .514 & & \\
\hline \multirow{2}{*}{ 3.Students use computers only is lab. } & Male & 21 & 2.52 & 1.209 & \multirow{3}{*}{-.320} & \multirow{3}{*}{.123} \\
\hline & Female & 14 & 2.64 & .842 & & \\
\hline \multirow{2}{*}{$\begin{array}{l}\text { 4.Students are more engaged in learning math- } \\
\text { ematics due to technology. }\end{array}$} & Male & 21 & 3.81 & .602 & & \\
\hline & Female & 14 & 3.57 & .756 & \multirow[t]{2}{*}{1.035} & \multirow[t]{2}{*}{.194} \\
\hline \multirow{2}{*}{$\begin{array}{l}\text { 5.Students' understanding of mathematics } \\
\text { subjects has deepened due to technology use. }\end{array}$} & Male & 21 & 3.81 & .928 & & \\
\hline & Female & 14 & 3.93 & .917 & \multirow[t]{2}{*}{-.373} & \multirow[t]{2}{*}{.730} \\
\hline \multirow{2}{*}{$\begin{array}{l}\text { 6.Students use technology in other subjects } \\
\text { aside from mathematics. }\end{array}$} & Male & 21 & 4.14 & .910 & & \\
\hline & Female & 14 & 4.50 & .519 & \multirow[t]{2}{*}{-1.327} & \multirow[t]{2}{*}{.097} \\
\hline \multirow{2}{*}{$\begin{array}{l}\text { 7.Students get good grades in mathematics } \\
\text { due to technology integration. }\end{array}$} & Male & 21 & 3.62 & .973 & & \\
\hline & Female & 14 & 3.64 & .745 & \multirow[t]{2}{*}{-.077} & .396 \\
\hline \multirow{2}{*}{$\begin{array}{l}\text { 8.Mathematics is more interesting and mean- } \\
\text { ingful to students when using graphics calcu- } \\
\text { lators and other technologies. }\end{array}$} & Male & 21 & 4.29 & .644 & & \multirow[b]{2}{*}{.341} \\
\hline & Female & 14 & 4.43 & .756 & -.600 & \\
\hline \multirow{2}{*}{$\begin{array}{l}\text { 9. Students become more confident in mathe- } \\
\text { matics due to technology integration. }\end{array}$} & Male & 21 & 4.19 & .873 & \multirow{3}{*}{.688} & \multirow{3}{*}{.605} \\
\hline & Femal & 14 & 4.00 & .679 & & \\
\hline \multirow{2}{*}{$\begin{array}{l}\text { 10.Improve students' behavioral engagement } \\
\text { during lessons and learn mathematics better }\end{array}$} & Male & 21 & 4.05 & .669 & & \\
\hline & Female & 14 & 4.00 & .679 & .702 & .205 \\
\hline
\end{tabular}

Significant: *p $<0.05$

\subsection{Group interviews}

The following can be concluded for the conducted group interviews: (1) All teachers agreed no strong support from the university like sending teachers to trainings for professional development with regards to technology in teaching-learning process and lack of equipment and facilities in technologies including rooms for instruction and for laboratory use; (2) Both male and female teachers complained about poor internet connection or wifi is not readily accessible; (3) Both male and female teachers said that there is lack of consultation regarding their specific needs in their subject area like what software is needed in teaching specific mathematics subject; (4) Some male and female teacher respondents claimed that teachers should use a variety of teaching methods in teaching mathematics; and (5) Some male and female teacher respondents admitted that they want to have their own different electronic gadgets or technology tools however, they could not afford to buy them due to financial constraints.

Furthermore, the respondents pointed out that their efforts in teaching mathematics with technology, though infrequently were motivated by their assess- mathematics. As one of the male teacher participants stated, "we use technology because it allows our students to be active learners and both teachers and learners benefited. "The participants also mentioned and claimed that the following are considered as incentives and rewards that the university should provide them: (1) digital support for media and e-books; (2) extra resources such as devices or access portal for operation of technology; (3) provide monthly training to all mathematics teachers regarding technology use and integration to teaching-learning process; (4) mathematics rooms with complete equipment like Television or projectors with internet access; (5) financial support for teachers to motivate them to integrate technology in teaching. Piotrowski and Vodanovich [22] believed that the availability of adequate rewards or compensation is also important and may influence teachers' use of technology. Incentives or rewards, according to them, can stimulate teachers to be more innovative within their teaching. If teachers are not provided with adequate rewards or incentives, or if the compensation they receive is no difference from their conventional teaching, teachers may not be motivated to upgrade their skills in using technology for teaching [23]. 


\section{Conclusion}

To shape plans and directions for future faculty development program involving technology integration not only in mathematics but also in other fields of the curricular programs of the university is indeed very crucial. The academic leaders such as Deans are also critical in creating an environment which should encourage and support effective teaching by setting priorities for the academic unit they supervise. They should focus on the curriculum design and once the integration has started and the teachers are already modeling the integration into coursework, including the trainings and expectations for all faculty is appropriate. This will take planning and allowing time for change and adoptions which may considered a big challenge not only for teachers but also for the entire academic community.

\section{Acknowledgment}

The researchers would like to extend their sincere thanks to Research and Development Office headed by Dr. Hermogenes M. Paguia, the Vice President for Research, Extension and Training, Dr. Rudy C. Flores, and to Dr. Gregorio J. Rodis, University President for their continuous support and for allowing us to conduct this research endeavor.

\section{References}

[1] Kotrlik, J., \& Redmann, D. (2005). Extent of technology integration in instruction by adult basic education teachers. Adult Education Quarterly: A Journal of Research and Theory, 55 (3), 200-219.

[2] Mundy, M.A., Kupczynsk, L. \& Kee, R. (2012). Teacher's Perceptions of Technology Use in the Schools, DOI: 10.1177/2158244012440813 http://sgo.sagepub.com.

[3] Wrights, C. (2001). Children and Technology: Issues, Challenges, and Opportunities, Childhood Education, 78(1), 37-41.

[4] Lam, Y., \& Lawrence, G. (2002). Teacher-student role redefinition during a computer-based second language project: Are computers catalysts for empowering change? Computer Assisted Language Learning, 15 (3), 295-315.

[5] Almekhlafi, A.G. (2006). The effect of computer assisted language learning (CALL) on United Arab Emirates English as a foreign language (EFL) school students' achievement and attitude. Journal of Interactive Learning Research, 17(2), 121-142.

[6] Posner, D. (2002). Education for the $21^{\text {st }}$ Century, Phi Delta Kappa, 84(4), 316-317.

[7] Luan, W.S., Fung, N.S., Nawawi, M. \& Hong, T.C. (2005). Experienced and Inexperienced Internet Users
Among Pre-service Teachers; Their Use and Attitudes Toward Internet, Educational Technology \& Society, 8(1), 90103.

[8] Zhao, Y. (1998). Designfor Adoption: The Development of an Integrated Web-based Education Environment, Journal \& Research on Computing Education, 30(3), 307328.

[9] Robertson, B. (2000). Integrating Technology into Instruction, Multimedia Schools, 7(2), 34-39.

[10] Best, J. W. (1970). Research in Education. New Jersey: Prentice-Hall.

[11] Middleton, B. M. \& Murray, E. D. (1999). The Impact of Instructional Technology on Student Academic Achievement in Reading and Mathematics. International Journal of Instructional Media, 26(1), 109-116.

[12] National Council of Teachers of Mathematics. (2008). The Role of Technology in the Teaching and Learning of Mathematics. Retrieved from http://www.nctm.org/ about/content.aspx ?id=14233.

[13] Hembree, R \& Dessart, D. J (1992). Research on calculators in mathematics education in J. Fey and C. Hirsch (eds), Calculators in Mathematics Education, National Council of Teachers of Mathematics, Reston VA, 23-32.

[14] Goddard, L. M. (2008). A Study of Teacher Perceptions of Instructional Technology Integration in the Classroom. Delta Pi Epsilon Journal. No. 2 Spr/Summ 2008.

[15] Ellington, A. J. (2006). The effects of non-CAS graphing calculators on student achievement and attitude levels in mathematics: A meta-analysis. School Science and Mathematics, 106(1), 16-26. Retrieved from http://ssmj.tamu.edu/

[16] Ellington, A. (2003). A meta-analysis of the effects of calculators on students' achievement and attitude levels in precollege mathematics classes. Journal for Research in Mathematics Education, 34(5), 433-463.

[17] Guerrero, Shannon, Walker, \& Norman \& Dugdale. (2004). Technology in support of middle grade mathematics: what have we learned? Journal of Computers In Mathematics and Science Teaching (1), 23.

[18] Cope, C., \& Ward, P. (2002). Integrating Learning Technology Into Classrooms: The Importance of Teachers' Perceptions. Educational Technology \& Society, 5(1), 6774.

[19] Dick, T. P., \& Hollebrands, K. F. (2011). Focus in high school mathematics: Technology to support reasoning and sense making. Reston, VA: NCTM.

[20] National Council of Teachers of Mathematics. (2015). Strategic Use of Technology in Teaching and Learning Mathematics. Reston, VA: Author. 
[21] Diem, R. A. (2000). Can it make a difference? Technology and the social studies. Theory and Research in Social Education, 28, 493-501.

[22] Piotrowski, C., \& Vodanovich, S. (2000). Are the reported barriers to internet-based instruction warranted? A synthesis of recent research. Education, 121(1), 48-53

[23] Khan, B. (1997). Web-based instruction. Englewood Cliffs, NJ: Educational Technology Publications. 